\title{
LETTER:
}

\section{FIRST LETTER FROM E. A. MARTEL TO JOVAN CVIJIĆ: THE BEGINNING OF MUTUAL COLLABORATION}

\author{
Jasminko MULAOMEROVIĆ ${ }^{1} \&$ Jasmina OSMANKOVIĆ ${ }^{1}$
}

The Archive of the Serbian Academy of Science and Art in Belgrade includes four letters, a picture postcard and a plain postcard sent by E A Martel to Jovan Cvijić. This correspondence covers the period from 1895 to 1925. Martel's communications are dated as follows:

29 March 1895 (letter)

14 January 1896 (plain postcard)

6 August 1897 (letter)

19 December 1924 (letter)

5 March 1925 (picture postcard)

11 March 1925 (letter).

As this shows, their correspondence covers a long period, and obviously the number of letters from one to the other over this period could not be counted in advance.

Three of the letters and the postcards are in French, while the first letter is in German. The content of Martel's correspondence in French has already been published (Mulaomerović 2016). His last letter is merely a list of contacts in the south of France which could be of use to Jovan Cvijić during his excursion in the spring of 1925 (Mulaomerović 2019).

This will be only a brief account of the first letter from Martel to Cvijić. It cover four pages, and was written on the letterhead of E A Martel's attorney's chambers. Translated to English, it reads:

Dear Sir,

I am delighted to have entered into correspondence with you. I have studied with great care your much appreciated book Karstphänomen and have used its bibliography for my own work Les Abîmes. I believe we are of the same opinion as to what causes swallow-holes and subterranean waters. I have safely received your new publication on the caves of eastern Serbia and thank you on behalf of the speleological society.

Unfortunately I do not understand the Slavonic language. It is only from the remarkable plans and your brief explanation in German that it is just possible to understand that there are wonderful hills in Serbia - swallowholes through subterranean water courses.

I very much regret that your abstract will not appear in the publication of the speleological society instead of in "Annales de géographie."

I ask you in future to reserve (?) your subterranean investigations for us (as regards French publications) and in addition request that you forward abstracts in German, which I shall be happy to translate.

My aim is to centralise all subterranean explorations and affairs with this speleological society. I hope that you will not refuse to be our valued and much appreciated associate for Serbia and its neighbours.

I cannot give you my opinion until I receive a review of your paper in German or French.

My works Cevennes and Abîmes comprise almost all my earlier, separate papers, much expanded of course. I shall send you offprints the papers not included in those two works.

We shall be very happy to receive a copy of your Karstphänomen, which I myself already possess.

The first bulletin will appear in early May.

Yours most sincerely,

E. A. Martel

${ }^{1}$ Center for Karst and Speleology, Sarajevo, e-mails: dodospeleo@gmail.com, jasmina.osmankovic@efsa.unsa.ba 

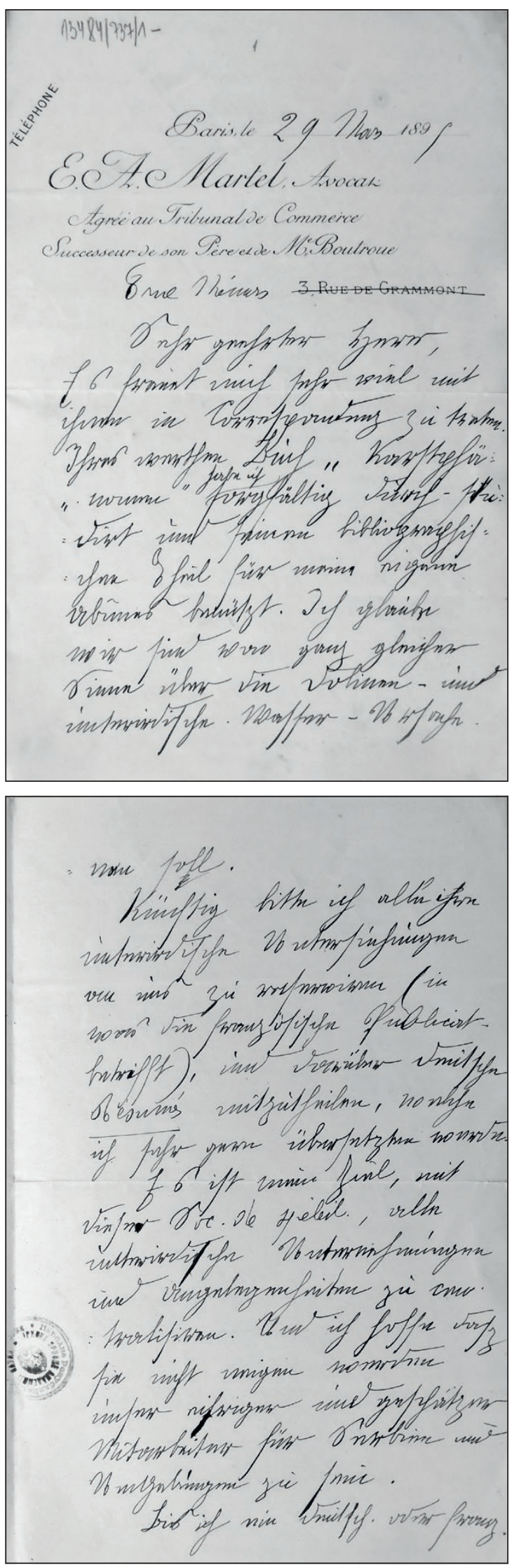

Vinif ifm Nhmin Prithichtio

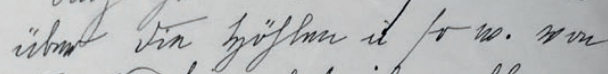
$\checkmark$ JA. Ontrim jutre if novfl as. - Coltrm inu in Thrma $\sqrt{m}$ vo de speled. Sunth if is/in

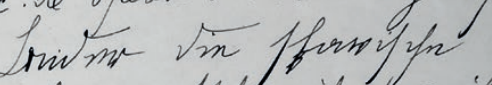

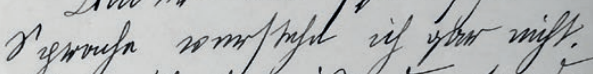
thim if ris tin forwims. bina oflirma nit ifra Plmin

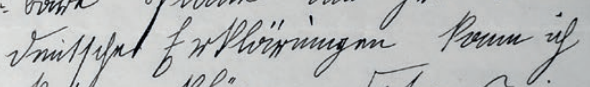
prima mithionm $\sqrt{20 / 3}$ no in Suntion noinummbins Lrawn bofringm vining iutnwitrifyn Linger yibt.

If minimm infac wint int ifw Besume mift in in pitticust. imn biflm: Hiwnon Vmallifort thatt $\sqrt{m \text { r }}$ vumalor $\sqrt{n}$ ymergming in m/fm:

1)

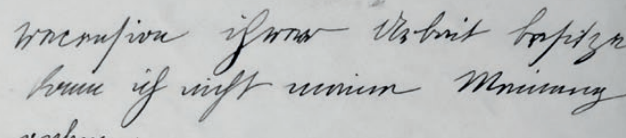
zomme $\sqrt{\text { in }}$ Coverns un Ghing mitfoltim fisft olle min

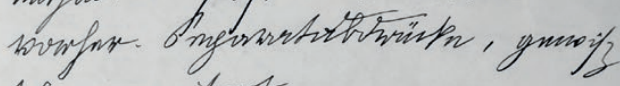
frifo mono nitmat. vif mon if ifrum

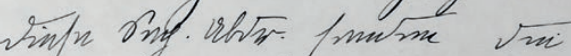
niff in vir finis thonath nu: - yntrinitf im?

$$
\text { pirt in fve. ol peleve. }
$$

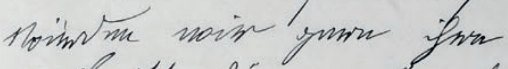
"Rrirft-yfócuroman "moleltme

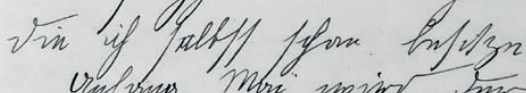

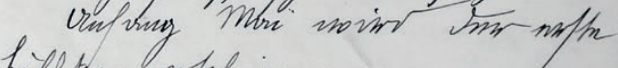
billotine moryminn

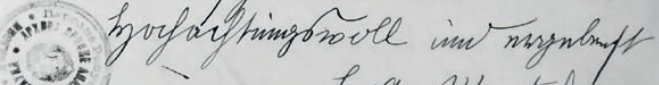
$\Rightarrow$ cich. Narte 
Note: A line (_) or (?) indicate parts of Martel's handwriting that the translator from the German found illegible or was uncertain of the intended meaning.

As the first sentence of this reveals, this was Martel's response to Cvijić's own first letter, which he sent with his books Karstphänomen, published in 1893, and Pećine i podzemna hidrografija u Istočnoj Srbiji, published in 1895. Since the latter was in Serbian, Cvijić included with it a brief summary in German. Martel acknowledges that he does not "at all understand the Slavonic language," and that it was only from the abstract, the plans of caves and the drawings that he gleaned some knowledge of karst in Serbia and its subterranean hydrography. As regards Cvijić's doctoral thesis, or book, Martel writes that he has studied it closely, having a copy in his private library, and that he has used the bibliography to supplement his own work Les Abîmes (first edition published in 1894). He notes that he shares Cvijićs views on the causes of the formation of swallow-holes and subterranean waters.

Martel expresses his regret that it will not be possible to publish the abstract in German of the book Pećine i podzemna hidrografija u Istočnoj Srbiji in Spelunca, the periodical of the Speleological Society, which had recently been founded and begun to issue its own publications, as Cvijić informed him that the abstract would appear in the periodical "Annales de géographie."

For this reason, Martel asks Cvijić to reserve all his future subterranean research for his speleological periodical, and to become a "valued and much appreciated" associate of the Speleological Society for Serbia and its neighbouring countries. ${ }^{2}$ This offer was part of E A Martel's strategy which T Shaw (1988) called his "international strategy," since he clearly stated to Cvijić that his "aim was to centralise all subterranean explorations and affairs" with the Speleological Society.

That same year Cvijić published his paper "La Grande grotte de Douboca, dans la Serbie orientale" in Spelunca vol III, followed later by two more papers, "Les glacières naturelles de Serbie" (1896) and "Brusque formation d'une doline en Serbie" (1897). Jovan Cvijić also figures as a corresponding member of the Société de spéléologie from its foundation in 1895 (Anon. 1895, Shaw 1988).

The end of the letter reveals that Cvijić was interested in Martel's papers, since Martel tells him about his books Cevennes and Les Abimes, which include "almost all [his] earlier papers, much expanded of course," and that he will send him offprints of his papers not included in the two books.

To encourage future collaboration, Martel ends by informing Cvijic that the first issue of the periodical Spelunca will appear in early May. The reference is to vol. I (January-March 1895).

Though short, this letter reveals that E A Martel was well informed about speleological investigations in the Dinarics, and that he saw in Jovan Cvijić a very useful future associate for the expansion of his "international strategy." The two were to collaborate right up to Cvijiçs death in 1927.

\section{ACKNOWLEDGEMENTS}

The authors thanks to the Archive of the Serbian Academy of Science and Art in Belgrade for providing the research opportunity.

\footnotetext{
${ }^{1}$ Cvijić published this review under the titles "pod naslovom Les cavernes et l'hydrographie souterraine de la Serbe orientale" in Annales de géographie in 1895 (pp. 137-138), in the section Bibliography for 1894, without giving the date of publication of his book, which appeared in 1895.

${ }^{2}$ In 1893 Martel visited Bosnia and Herzegovina (Andre et al.1997, Kranjc \& Kranjc 1988, Mulaomerović 2019), and evidently failed to find anyone he could rely on in his future investigations. Wiktor Apfelbeck, curator of the Provincial Museum in Sarajevo, was present at the inaugural meeting of the Société de spéléologie, and submitted a paper on the subterranean fauna of Bosnia and Herzegovina, but was not among the Society's first members. Membership of the society clearly also had political condittions. The list of members for 1904 (Shaw 1988) reveals that one member was from Bosnia.
} 


\section{REFERENCES}

Anon., 1895: Liste des Members (150) au 1er Mai 1895. - Spelunca - Bulletin de la Societé de Spéléologie, 1(1):15-19.

André D., Casteret M., Carlier P., Gautier A., Kalliatakis G., Renouard C. \& L. Renouard, 1997: La plume et les gouffres : correspondance d'Edouard Alfred Martel (de 1868 à 1936) avec Norbert Casteret, Robert de Joly, Louis Balsan et les nombreux pionniers de la spéléologie française.- Meyrueis: Association E. A. Martel, 610 pp.

Kranjc A. \& M. Kranjc, 1988: E. A. Martel na jugoslovanskem krasu (Prispevek k 100-letniciorganiziranega jamarstva v Sloveniji).- Naš krš XIV(24-25): 149-158.

Mulaomerović, J. 2016: Edouard Alfred Martel and Jovan Cvijić: Excerpts from the correspondence. 2936.- In: 150th Anniversary of Jovan Cvijićs birth:
Proceedings of the International Conference held at the Serbian Academy of Sciences and Arts, October 12-14, 2015. Beograd : Serbian Academy of Sciences and Arts, $356 \mathrm{pp}$.

Mulaomerović J., 2019. E. A. Martel's letter to Jovan Cvijić: Preparations for excursion to South France in 1925. 62-67. In: [J. Mulaomerović, Ed.], Proceedings of the International Symposium on Hystory of Speleology and Karstology in Alps, Carpathians and Dinarides, ALCADI 2018. Sarajevo : Center for Karst and Speleology, 95 str.

Mulaomerović J., 2019: E. A. Martel u Bosni i Hercegovini.- Naš krš XXXIX (52): 5-10.

Shaw T.R., 1988: Martel's visit to Mendip in 1904. Part of his international strategy?- Proceedings, University of Bristol Spelaeological Society, 18(2): 278-291.

\section{APPENDIX: THE ORIGINAL GERMAN TEXT OF THE LETTER}

Paris, le 29 Mars (?) 189_(?)

E. A. Martel, Avocat

Agree au Tribunal de Commerce

Successeur de son Pere et. de MeBoutroue

8 rue

Sehr geehrter Herr,

Es freut mich sehr viel mit Ihnen in Correspondenz zu treten. Ihres werthen Buch „Karstphänomen“ habe ich sorgfältig durchstudirt und seinen bibliographischen Theil für meine eigene Abîmes benützt . Ich glaube wir sind von ganz gleicher Sinne über die Dolinen - und unterirdische Wasser-Ursache.

Auch Ihre neue Publication über die Höhlen von Ost. Serbien habe ich wohl erhalten und in Name (?) der Soc. de Speleo. danke ich dafür.

Leider die slavische Sprache verstehe ich gar nicht. Nur aus die sonderbare Pläne und ihre kleine deutsche Erklärungen kann ich kaum erklären, dass es in Serbien wunderbaren Berge - Bohrungen durch unterirdische Bäche gibt.

Ich bedauere sehr viel, dass ihr Resume nicht in die
Publicat. Der Höhlenkunde (?) Gesellschaft statt der Annales de geographie erscheinen (?) soll.

Künftig bitte ich alle ihre unterirdische Untersuchungen an uns zu reservieren (?) (in was die französische Publicat. betrifft), und darüber deutsche Resumes mitzuteilen, welche ich sehr gerne übersetzen werde.

Es ist mein Ziel, mit dieser Soc. de speleol., alle unterirdische Untersuchungen und Angelegenheiten zu centralisieren. Und ich hoffe dass Sie nicht neigen werden unser eifriger und geschätzer Mitarbeiter für Serbien und Umgebungen zu sein.

Bis ich nun deutsch oder franz. Recension ihrer Arbeit besitze kann ich nicht meine Meinung geben.

Die Cevennes und Abîmes enthalten fast alle meine vorher. Separatabdrücke, gewiss sehr erweitert.

Doch werde ich Ihnen diese Sep. Abdr. senden die nicht in die beide Werke _ gedruckt sind.

Für (?) die Soc. de Speleol. werden (?) wir gern ihr „Karstphänomen“ erhalten, die ich selbst schon besitze. Anfang Mai wird der erste Bulletin erscheinen Hochachtungsvoll und ergebenst, E. A. Martel 